\title{
НОРМАТИВНО-ПРАВОВЕ ЗАБЕЗПЕЧЕННЯ ЕКОНОМІЧНОЇ ЕКСПЕРТИЗИ: СТАН ТА ВДОСКОНАЛЕННЯ
}

\section{REGULATORY AND LEGAL SUPPORT OF ECONOMIC EXAMINATION: STATE AND IMPROVEMENT}

\author{
Мулик Ярославна Ігорівна \\ кандидат економічних наук, доцент, \\ Вінницький національний аграрний університет \\ ORCID: https://orcid.org/0000-0002-8166-2481
}

\author{
Mulyk Yaroslavna \\ Vinnytsia National Agrarian University
}

\begin{abstract}
У статті досліджено основні нормативно-правові акти, що регулюють порядок організації та проведення судових експертиз та роботу експертів. Охарактеризовано структуру та зміст розділів Закону України «Про судову експертизу», представлено погляди науковців на питання, що потребують змін та вдосконалення. Охарактеризовано зміст Інструкції про призначення та проведення судових експертиз та експертних досліджень № 53/5 та необхідність її вдосконалення а також Науково-методичні рекомендації з питань підготовки та призначення судових експертиз та експертних досліджень. Досліджено права, обов'язки та відповідальність, що регулюються різними нормативно-правовими актами, визначено, які є неточності та недоліки. Запропоновано розширення правових фрункцій судового експерта-економіста. Досліджено нормативні акти в сфрері атестації судових експертів. Представленні в дослідженні удосконалення нормативно-правої бази судово-економічних експертиз, впливатимуть на підвищення ефективності проведення судово-економічних експертиз та роботи судових експертів.
\end{abstract}

Ключові слова: економічна експертиза, судова експертиза, експерт, судовий експерт, атестація судових експертів, нормативно-правове забезпечення.

В статье исследованы основные нормативно-правовые акты, регулирующие порядок организации и проведения судебных экспертиз и работу экспертов. Охарактеризованы структура и содержание разделов Закона Украины «О судебной экспертизе», представлены взгляды учёных на вопросы, требующие изменений и совершенствования. Охарактеризованы содержание Инструкции о назначении и проведении судебных экспертиз и экспертных исследований № 53/5 и необходимость её совершенствования, а также Научно-методические рекомендации по вопросам подготовки и назначения судебных экспертиз и экспертных исследований. Исследованы права, обязанности и ответственность, которые регулируются различными нормативно-правовыми актами, определено, какие есть неточности и недостатки. Предложено расширение правовых функций судебного эксперта-экономиста. Исследована нормативные акты в сфере аттестации судебных экспертов. Представленные в исследовании усовершенствования нормативно-правовой базы судебно-экономических экспертиз, влиять на повышение эффрективности проведения судебно-экономических экспертиз и работы судебных экспертов.

Ключевые слова: экономическая экспертиза, судебная экспертиза, эксперт, судебный эксперт, аттестация судебных экспертов, нормативно-правовое обеспечение.

The article examines the main legal acts governing the organization and conduct of forensic examinations and the work of experts. The structure and content of sections of the Law of Ukraine "On Forensic Science" are described, the views of scholars on issues that need to be changed and improved to create conditions for proper and effective expert support of justice and restart the entire system of forensic examinations, opportunities for forensic experts and private to work honestly transparently and in conditions of professional competition. The content of the Instruction on appointment and conduct of forensic examinations and expert research № 53/5 and the need for its improvement are described, as well as scientific and methodological recommendations on preparation and appointment of forensic examinations and expert research, regulating the main tasks of various types of examinations, indicative list of issues studied, the list of documents under study. The rights, duties and responsibilities regulated by various legal acts are studied, differences, inaccuracies and shortcomings are identified. It is proposed to expand the legal functions of a forensic economist, to represent responsibility equally in regulations, which should clearly define 
what violations by the expert can be committed and what responsibility he will bear. Normative acts in the field of attestation of forensic experts are studied and it is noted that there are certain gaps, unresolved issues, which leads to a long time of waiting for the results of examination by its initiators, significant workload of experts and involvement of low-skilled persons in the examination process. It is noted that the practice shows the existence and need to improve the weaknesses of the process of economic expertise in Ukraine, because it is an outstanding means of protecting the interests of individuals and legal entities, promotes effective investigation, performs a number of important tasks to identify violations of labor legislation. offenses in the organization of labor, as well as ensures the development of proposals for the prevention of negative phenomena. Currently, in the process of economic expertise there are a number of problems, to overcome which in the future it is necessary to introduce changes to existing legislation aimed at improving the regulation and organization of economic expertise. The improvements in the legal framework of forensic economic expertise presented in this study will increase the efficiency of forensic economic expertise and the work of forensic experts.

Keywords: bank capital, fixed capital, additional capital, authorized capital, regulatory capital, bank capital ratios, capital adequacy.

Постановка проблеми. Господарюючі суб'єкти в ході своєї діяльності регулярно мають справи 3 господарськими спорами. За таких обставин есрективним важелем захисту $є$ економічна експертиза кваліфрікованим фрахівцем в певній галузі, що ставить за мету дослідження різного виду документів про діяльність підприємства, фрінансового та податкового обліку, звітності тощо.

Під економічною експертизою слід розуміти дослідження певних проблем, що виникають в процесі економічної діяльності суб'єкта господарювання і потребують кваліфрікованих дій експертів для досягнення визначеної мети та розв'язання конкретних завдань, пов'язаних із веденням бухгалтерського обліку, фрінансовоекономічною діяльністю та фрінансово-кредитними операціями, а також для запобігання загрозам та ризикам такого суб'єкта [1, с. 37].

Ефективність проведення економічних експертиз та перспективи її розвитку багато в чому залежать від державної політики в цій сорері. Належна якість проведення судових експертиз переважно залежить від правильного планування, організації та проведення експертної діяльності. Необхідно також відзначити, що експерти мають працювати в рамках нормативно-правового поля, яким чітко визначено їх завдання, фрункції, обов'язки та права, відповідальність. Важлива роль в цьому відводиться наявній нормативно-правовій базі, яка регулює ці всі питання, тому особливої актуальності набувають питання дослідження нормативно-правового забезпечення економічної експертизи.

Аналіз останніх досліджень та публікацій. Питання організації та проведення судово-економічних експертиз досить активно розглядаються в наукових дослідженнях. Оцінка фрахових джерел свідчить про наявність достатньої кількості підручників і навчальних посібників, монографрій, статей та дисертацій, де всебічно висвітлюють теоретико-методологічні та організаційні аспекти судових експертиз. Серед науковців, що займається даною проблематикою слід відмітити: Базась М. Ф., Дусренюк О. М., Капусник К. В., Михальчишина Л. Г., Мисак Г. В., Павлюк Д. Є., Натуркач Н. Є., Панченко І. А., Отенко В. І., Парфентій Л. А., Понікаров В. Д., Разборська О. О., Світлоока В. Ф., Романів С. Р., Федчишина В. В., Мулик Я. І., Ротару Т. В., Хомутенко О. В., Крівцова Т. О., Тищенко Д. О., Дікань Л. В., Ужва А. М., Кошинець М. І. та інші. Проте переважна більшість вчених у своїх дослідженнях висвітлюють теоретико-методологічні та практичні аспекти здійснення експертної діяльності.

Виділення невирішених раніше частин загальної проблеми. Незважаючи на багатоаспектний діапазон досліджень із даної проблематики, поодинокі питання й донині залишаються замало вивченими, дослідженими та опрацьованими. Зокрема, це стосується нормативно-правового забезпечення експертної діяльності.

Формулювання цілей статті. Метою статті $€$ дослідження стану нормативно-правового забезпечення економічної експертизи та визначення напрямів її вдосконалення.

Виклад основного матеріалу дослідження. Нормативно-правове забезпечення для судових експертиз різних видів відіграє важливе значення для виконання вимоги високоякісної реалізації намічених завдань. Нині в Україні прийнято ряд нормативно-правових актів, що регулюють питання організації та проведення судових експертиз.

Так, основним нормативним документом в цій галузі виступає Закон України «Про судову експертизу» № 4038-XII від 25.02.1994 [11]. Цей Закон визначає правові, організаційні і фрінансові основи судово-експертної діяльності з метою забезпечення правосуддя Укра- 
їни незалежною, кваліфрікованою і об'єктивною експертизою, орієнтованою на максимальне використання досягнень науки і техніки.

Він складається із 4 розділів, в яких представлені [11]:

- загальні положення - поняття судової експертизи, законодавство України про судову експертизу, гарантії незалежності судового експерта та правильності його висновку, забезпечення умов праці судового експерта за місцезнаходженням об'єктів дослідження, суб'єкти судово-експертної діяльності, підстави проведення судової експертизи (обстеження і дослідження), науково-методичне та організаційно-управлінське забезпечення судово-експертної діяльності, державний Реєстр атестованих судових експертів;

- інфоормація про судових експертів особи, які можуть (не можуть) бути судовими експертами; обов'язки та права судового експерта, їх відповідальність;

- фрінансове та організаційне забезпечення судово-експертної діяльності фрінансування судово-експертної діяльності; атестація судового експерта; експертно-кваліфрікаційні комісії; оплата праці та соціальний захист судових експертів; охорона державних спеціалізованих установ, що проводять судові експертизи; інфрормаційне забезпечення; кадрове забезпечення;

- міжнародне співробітництво в галузі судової експертизи - проведення судової експертизи за дорученням відповідного органу чи особи іншої держави; залучення фрахівців 3 інших держав для спільного проведення судових експертиз; міжнародне наукове співробітництво [11].

Цим Законом визначено, що судова експертиза - це дослідження на основі спеціальних знань у галузі науки, техніки, мистецтва, ремесла тощо об'єктів, явищ і процесів 3 метою надання висновку з питань, що $є$ або будуть предметом судового розгляду [11].

Розглядаючи Закон України «Про судову експертизу», Пиріг І.В. [9, с. 115] звертає увагу на окремі положення, що неодноразово розглядалися науковцями та потребують удосконалення. Починаючи з преамбули, у якій зазначається, що: «цей закон визначає правові, організаційні і фрінансові основи судово-експертної діяльності...», хоча в назві йдеться про «судову експертизу». Зрозуміло, що різниця в поняттях «судова експертиза» й «судово-експертна діяльність» досить суттєва, тому Закон повинен мати назву «Про судово-експертну діяльність».
Про доцільність прийняття нового Закону зазначають Хомутенко В. П. та Костіна О. Ю. та відмічають, що нині спільнота експертівпрактиків очікує прийняття проекту Закону України «Про судово-експертну діяльність в Україні» задля створення умов для належного та ефективного експертного забезпечення правосуддя та перезапуску всієї системи судових експертиз, можливості судовим експертам державних установ і приватним працювати чесно, прозоро та в умовах профресійної конкуренції [13, с. 59].

23 жовтня 2020 року Міністерство юстиції України на офріційному сайті опублікувало оголошення про винесення на публічне громадське обговорення проєкту Закону України «Про судово-експертну діяльність». Проєкт Закону України «Про судово-експертну діяльність» розроблено на виконання Указу Президента України від 08.11.2019 № 837 «Про невідкладні заходи з проведення реформ та зміцнення держави», яким передбачено, зокрема, необхідність врегулювання питань щодо самоврядування судових експертів, рецензування висновку судового експерта та визначення граничних строків проведення судових експертиз.

Пиріг І.В. зазначає, що у загальних положеннях Закону потрібно обов'язково роз'яснити зміст основних термінів, що складають основу судово-експертної діяльності. Обов'язковим $€$ роз'яснення термінів: «спеціальні знання», «судово-експертна діяльність», «державна судово-експертна діяльність», «судова експертиза». Також потрібно надати визначення понять: «судово-експертний заклад», «керівник судово-експертного закладу», «предмет, об'єкти судової експертизи», «зразки для дослідження». Також підлягають визначенню й детальному опису види та порядок проведення різного виду експертиз: первинної, повторної, додаткової, комплексної, комісійної [9, с. 115].

Ми також притримуємось цієї думки і пропонуємо в I розділі «Загальні положення» передбачити статтю «Понятійний апарат судової експертизи» де необхідно подати різні визначення, в тому числі і за видами експертиз - криміналістична, інженерно-технічна, економічна, товарознавча, експертиза у сфері інтелектуальної власності, психологічна, мистецтвознавча, екологічна, військова, судововетеринарна, гемологічна [6, с. 137].

Згідно статей 7, 8 Закону України «Про судову експертизу» та з метою забезпечення єдиного підходу до проведення судових експертиз та підняття їх якості, затверджено Інструкцію про призначення та проведення судових експертиз 


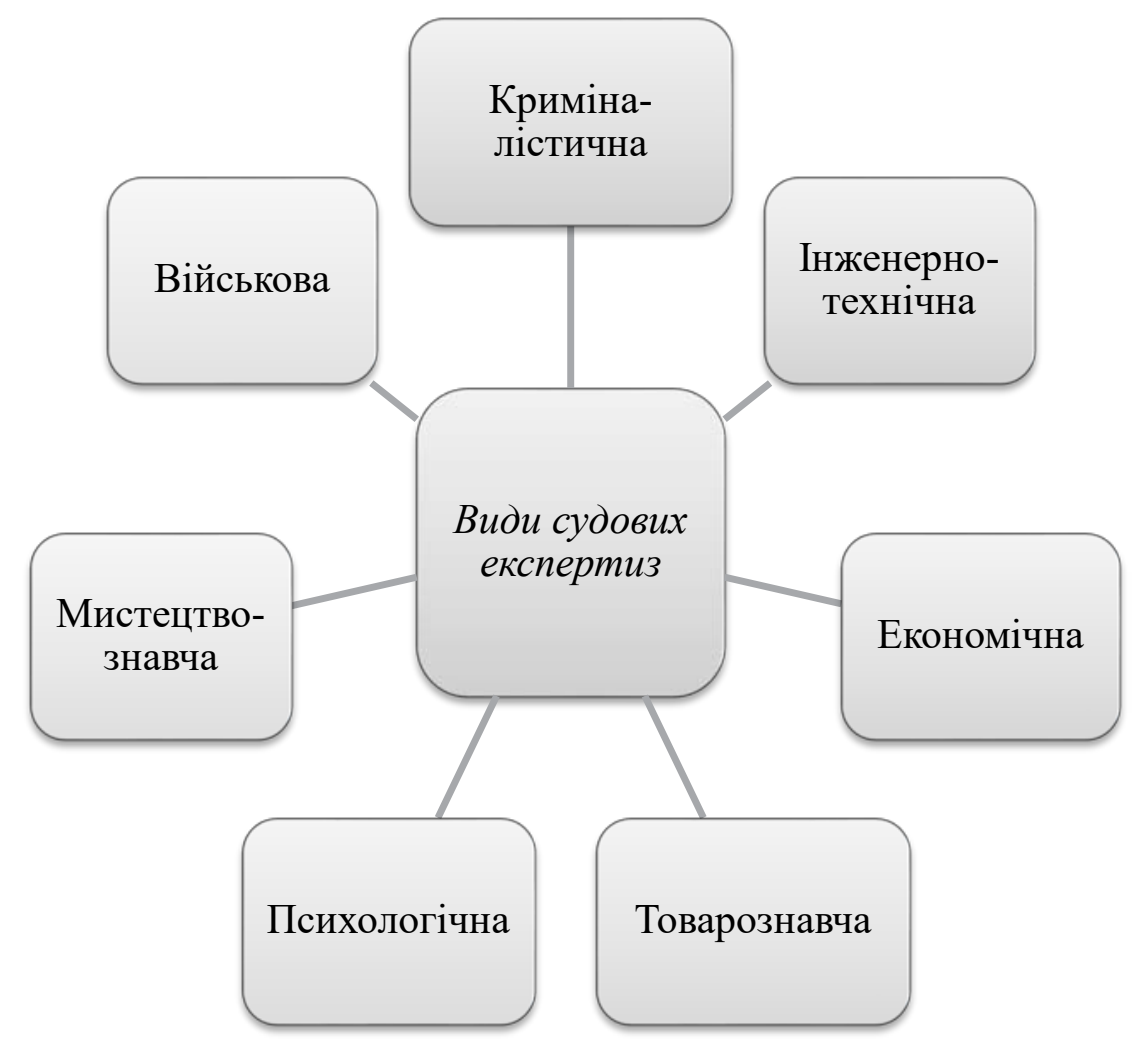

Рис. 1. Види судових експертиз в Україні [3]

та експертних досліджень (далі - Інструкція) [3] та Науково-методичні рекомендації 3 питань підготовки та призначення судових експертиз та експертних досліджень [8].

Інструкція [3] визначає основні типи експертиз (рис 1.), види експертних установ за зонами регіонального обслуговування (рис. 2), строки проведення експертиз, права, обов'язки та відповідальність експерта, офрормлення матеріалів для проведення експертиз (досліджень), порядок організації проведення експертиз (досліджень) та оформлення їх результатів.

Ознайомившись 3 Інструкції про призначення та проведення судових експертиз та експертних досліджень, доцільно передбачити крім завдань, предмет та об'єкти експертиз [6, с. 137] про що ми відображали в попередніх дослідженнях.

Науково-методичні рекомендації з питань підготовки та призначення судових експертиз та експертних досліджень [8] регулюють основні завдання різних видів експертиз, орієнтовний перелік вирішуваних питань, що вивчаються, перелік документів, що досліджуються, тощо. Так, ними врегульовано питання щодо економічної експертизи, де передбачено:

- дослідження документів бухгалтерського, податкового обліку і звітності;
- дослідження документів про економічну діяльність підприємств і організацій;

- дослідження документів фрінансово-кредитних операцій [8].

Експерт економічної експертизи, незалежно від сорери їі здійснення, напряму судового процесу чи справи, є активним суб'єктом судочинства та несе відповідальність за свої дії. В зв'язку з цим $€$ сенс навести права, обов'язки та відповідальність (рис. 3,4$)$, якими наділений судовий експерт згідно з Інструкцію про призначення та проведення судових експертиз та експертних досліджень [3].

Необхідно зазначити, що права та обов'язки експерта визначені також у таких нормативних актах: Закон України «Про судову експертизу» [11], Інструкція про особливості здійснення судово-експертної діяльності атестованими судовими експертами, що не працюють у державних спеціалізованих експертних установах [2], Цивільно- та Кримінально-процесуальними кодексами і вони дещо різняться між собою, мають недоліки.

Погоджуємось із думкою Ківшової Т. О., яка зазначає, що в жодному нормативно-правовому акті не йде мова про те, що судовий експерт чи відповідна експертна установа повинні виявляти та досліджувати умови, які сприяли здійсненню економічних порушень. 


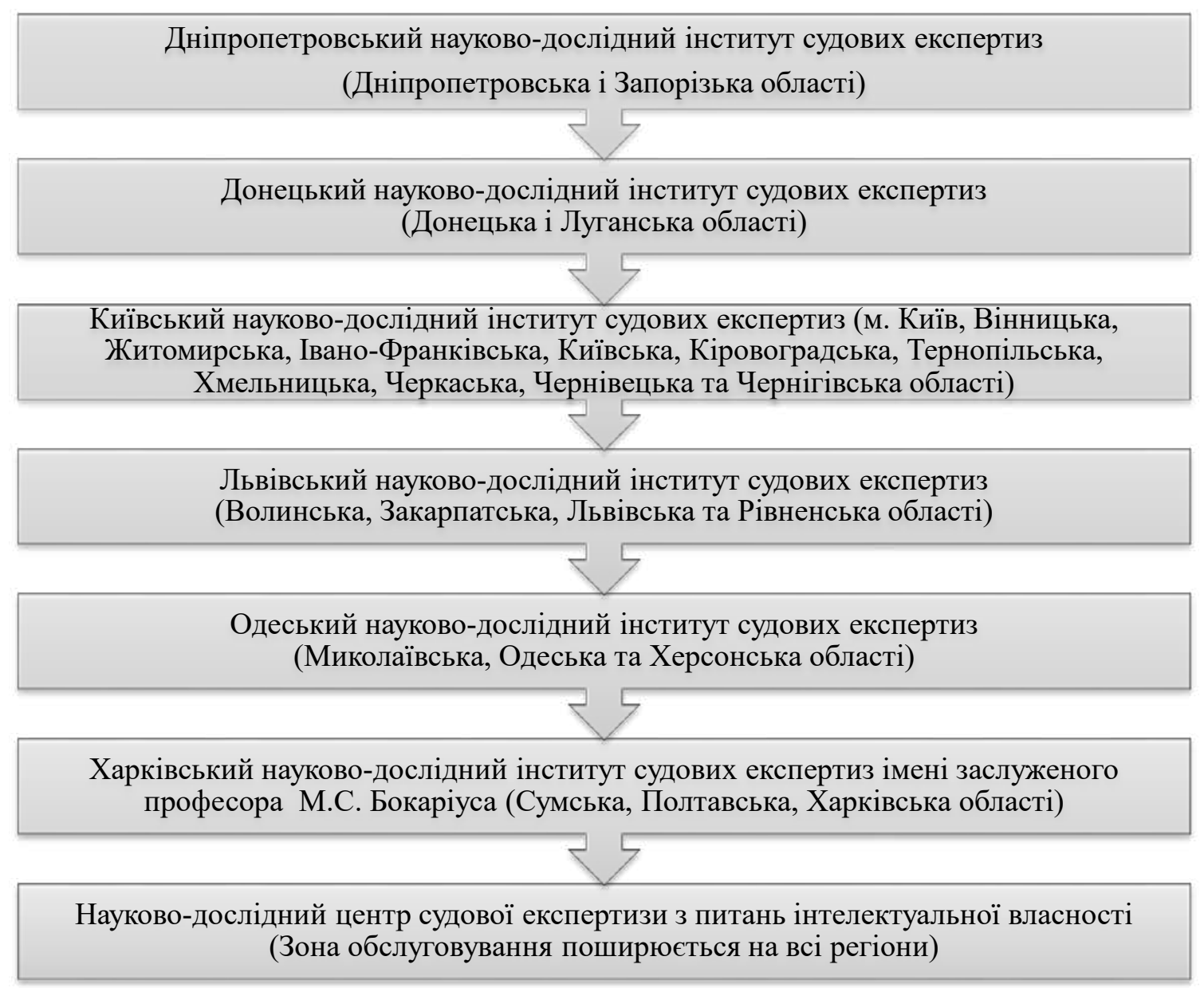

Рис. 2. Склад регіональних зон обслуговування науково-дослідних установ судових експертиз Міністерства юстиції України [3]

До того ж, у законодавстві чітко не прописано, що судовий експерт-економіст повинен надавати як суб'єктам господарської діяльності, так і органам державної влади певні рекомендації щодо усунення виявлених порушень та щодо проведення певних профрілактичних дій. При цьому, при проведенні судово-економічної експертизи, судовий експерт надає висновок у розрізі економічних аспектів дослідження. Правової ж оцінки діям, які сприяли вчиненню злочину (у разі виявлення останнього), судовий експерт-економіст (згідно 3 чинним законодавством України) надавати не має права [5, с. 50]. Крівцова Т. О. також вважає, що недостатніми правами, наділений судовий експерт-економіст, що значно обмежує його дії, а звідти збільшується час на здійснення судово-економічної експертизи та має місце недостатня кількість та якість доказів. На думку автора, з метою вдосконалення процесу проведення судової експертизи та сприяння зменшенню рівня економічної злочинності в державі в галузі судово-еконо- мічної експертизи необхідно першочергово переглянути існуюче законодавство, доповнити його та розширити в розрізі надання експертам-економістам певних правових срункцій (рис. 5) [5, с. 50]. Ми погоджуємось 3 науковцем, що реалізація зазначених правна забезпечить: скорочення часу на проведення судово-економічної експертизи; збільшення рівня розкриття економічної злочинності; підвищення економічної обізнаності суб'єктів господарської діяльності; зменшення рівня економічної злочинності [5, с. 51].

Автором також пропонується створити такі умови, за яких судовий експерт-економіст досліджує справу не лише в розрізі бачення іiї слідчим, прокурором, суддею та відповідає виключно на ті питання, які зазначені в постанові на її проведення, а самостійно, на свій власний розсуд, після вивчення матеріалів справи та вже у співпраці з тими ж органами досудового слідства, органами прокуратури чи суду, розробляє дієвий алгоритм роботи, за яким і має бути проведено судову експертизу [5, с. 50]. 


\section{Права та обов'язки експерта}

Експерт має право:

- ознайомлюватися з матеріалами справи, які стосуються предмета експертизи;

- відповідно до процесуального законодавства заявляти клопотання про надання додаткових

матеріалів і зразків та вчинення інших дій, пов'язаних із проведенням експертизи;

- у разі виникнення сумніву щодо змісту та обсягу доручення невідкладно заявляти клопотання

органу, який призначив експертизу, щодо уточнення поставлених експертові питань;

- $з$ дозволу органу, який призначив експертизу, бути присутнім під час проведення

процесуальних, виконавчих дій та ставити питання учасникам процесу;

- указувати у висновку експерта на оракти, виявлені під час проведення експертизи, які

мають значення для справи, але стосовно яких йому не були поставлені питання, та на

обставини, що сприяли (могли сприяти) вчиненню правопорушення;

- у разі незгоди з іншими членами експертної комісії складати окремий висновок;

- викладати письмово відповіді на питання, які ставляться йому під час надання роз'яснень

чи показань;

- оскаржувати в установленому законодавством порядку дії та рішення органу, який

призначив експертизу, що порушують права експерта або порядок проведення експертизи;

- на забезпечення безпеки за наявності відповідних підстав;

- одержувати винагороду за проведення експертизи та відповідно до законодавства

компенсацію витрат за виконану роботу та витрат, пов'язаних із викликом для надання

роз'яснень чи показань, у разі якщо це не є його службовим обов'язком.

\section{Обов'язки експерта:}

- заявити самовідвід за наявності передбачених законодавством обставин;

- прийняти до виконання доручену йому експертизу;

- особисто провести повне дослідження, дати обґрунтований та об'єктивний письмовий

висновок на поставлені питання, а в разі необхідності роз'яснити його;

- повідомити в письмовій фрормі органу, який призначив експертизу, про неможливість ії

проведення та повернути надані матеріали справи та інші документи;

- з'явитися на виклик органу, який призначив експертизу, для надання роз'яснень, показань

чи доповнень з приводу проведеної експертизи або причин повідомлення про неможливість

ії̈ проведення;

- забезпечити збереження об'єкта експертизи;

- не розголошувати без дозволу органу, який призначив експертизу, відомості, що стали йому відомі у зв'язку з виконанням обов'язків.

Рис. 3. Права та обов'язки експерта [3]

\section{Відповідальність експерта}

\section{Відповідальність експерта: \\ - за надання завідомо неправдивого висновку, за відмову без поважних причин від виконання покладених на нього обов'язків, а також за розголошення даних, що стали йому відомі під час про- ведення експертизи, експерт несе кримінальну відповідальність згідно з чинним законодавством; - за злісне ухилення від явки до органів досудового розслідування або суду експерт несе адміністративну відповідальність згідно з чинним законодавством; \\ - за допущені порушення під час проведення експертизи, що не тягнуть за собою кримінальної чи адміністративної відповідальності, експерт може бути притягнутий до дисциплінарної відповідальності згідно з чинним законодавством; \\ - у разі завдання своїми діями майнової шкоди під час проведення експертизи експерт несе матеріальну відповідальність згідно з чинним законодавством.}




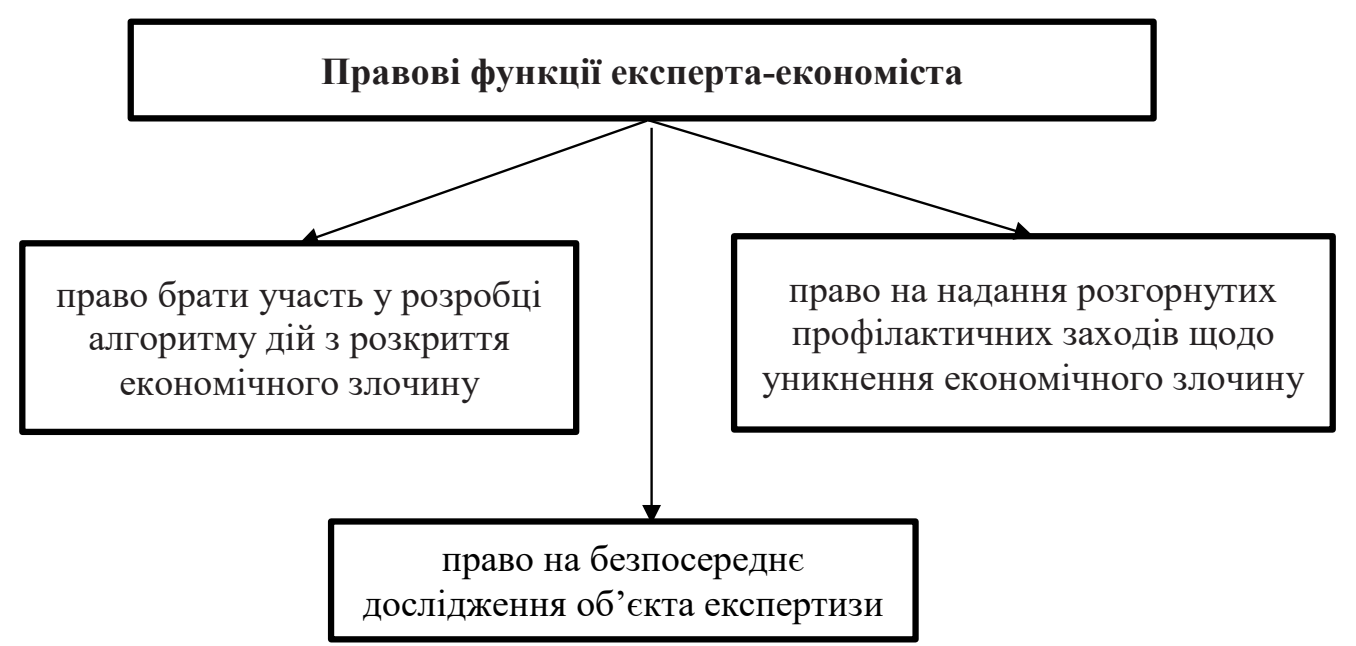

Рис. 5. Основні напрямки розширення правових функцій судового експерта-економіста

Джерело: [5, с. 51]

Як зазначалось раніше, в процесі проведення експертиз, експерти можуть керуватись також Інструкцією про особливості здійснення судово-експертної діяльності атестованими судовими експертами, що не працюють у державних спеціалізованих експертних установах [2]. Як відмічають науковці та практики між цими інструкціями [2; 3] $€$ певні розбіжності. Так, Кошинець М. І. [4, с. 171] зазначає, що окрім загальних структурних відмінностей між названими інструкціями, вони різняться між собою навіть в частині визначення прав і обов'язків експерта, що, на думку автора, вносить певні неузгодженості в узагальнюючі результати проведених експертиз.

Автор зазначає, що якщо провести аналіз прав експертів, бачимо, що вони майже не різняться як за складом, так і за змістом. Єдиною відмінністю $€$ право проводити експертизу на договірних засадах. Але цей пункт можна віднести швидше не до прав, а до організаційних особливостей здійснення експертизи атестованими судовими експертами, що не працюють у державних спеціалізованих експертних установах. Порівняння обов'язків експерта за обома інструкціями дає аналогічний, який знову ж таки уточнює організаційний момент [4, c. 171].

Кошинець М. І. резюмує, що більш доцільно було б мати єдину інструкцію методичного плану та 2 різні інструкції з організації проведення експертиз [4, с. 171].

Подібна ситуація характерна і для відповідальності, що має нести експерт за свої діяння. В таблиці 1 наведено види відповідальності експерта, що передбачені в різних нормативних актах. Як бачимо, вони різняться між собою. В Законі України «Про судову експертизу» [11] та Інструкції № 3505/5 [2] вона представлена в досить узагальненому та обмеженому вигляді. Вважаємо, що відповідальність має бути однаково представлена в цих нормативно-правових актах, де чітко має бути визначено, які порушення 3 боку експерта можуть бути допущені і яку відповідальність він буде нести.

Свою діяльність експерти можуть проводити при наявності свідоцтва про атестацію. Інорормація про атестованих судових експертів відображається в Реєстрі, ведення якого регулюється Порядком ведення державного Реєстру атестованих судових експертів, затвердженим наказом Міністерства юстиції України від 29.03.2012 № 492/5 [10]. Ним визначено, що Реєстр - це офріційна електронна база даних, що ведеться з метою створення інформаційного фронду про осіб, які отримали в порядку, передбаченому Законом України «Про судову експертизу», квалісрікацію судового експерта [10].

Реєстр складається 3 відомостей про атестованих судових експертів Міністерства юстиції України, Міністерства охорони здоров'я України, Міністерства внутрішніх справ України, Міністерства оборони України, Служби безпеки України, Державної прикордонної служби України та судових експертів, які не $€$ працівниками державних спеціалізованих установ [7].

В Реєстрі фріксується інфрормація: прізвище, ім'я, по батькові судового експерта; найменування Експертно-кваліфрікаційної комісії 
Таблиця 1

Відповідальність судового експерта, що регулюється різними нормативно-правовими актами

\begin{tabular}{|c|c|c|}
\hline $\begin{array}{c}\text { Закон України } \\
\text { «Про судову } \\
\text { експертизу», } \\
4038-X I I\end{array}$ & Інструкція № 53/5 & $\begin{array}{l}\text { Інструкція } \\
\text { № } 3505 / 5\end{array}$ \\
\hline \multicolumn{3}{|c|}{ Відповідальність } \\
\hline $\begin{array}{l}\text { Судовий експерт } \\
\text { на підставах } \\
\text { і в порядку, } \\
\text { передбаченими } \\
\text { законодавством, } \\
\text { може бути } \\
\text { притягнутий } \\
\text { до юридичної } \\
\text { відповідальності } \\
\text { (розділ II, ст. 14) }\end{array}$ & $\begin{array}{l}\text { 1. За надання завідомо неправдивого висновку, } \\
\text { за відмову без поважних причин від виконання } \\
\text { покладених на нього обов'язків, а також за } \\
\text { розголошення даних, що стали йому відомі } \\
\text { під час проведення експертизи, експерт несе } \\
\text { кримінальну відповідальність згідно з чинним } \\
\text { законодавством. } \\
\text { 2. За злісне ухилення від явки до органів } \\
\text { досудового розслідування або суду експерт несе } \\
\text { адміністративну відповідальність згідно з чинним } \\
\text { законодавством. } \\
\text { 3. За допущені порушення під час проведення } \\
\text { експертизи, що не тягнуть за собою кримінальної } \\
\text { чи адміністративної відповідальності, експерт } \\
\text { може бути притягнутий до дисциплінарної } \\
\text { відповідальності згідно з чинним законодавством. } \\
\text { 4. У разі завдання своїми діями майнової шкоди } \\
\text { під час проведення експертизи експерт несе } \\
\text { матеріальну відповідальність згідно з чинним } \\
\text { законодавством. (розділ ІІ, п. 2.4) }\end{array}$ & $\begin{array}{l}\text { За наданий } \\
\text { висновок судовий } \\
\text { експерт відповідає } \\
\text { згідно з чинним } \\
\text { законодавством } \\
\text { України (розділ II, } \\
\text { п. 5) }\end{array}$ \\
\hline
\end{tabular}

Джерело: побудовано автором на основі [2; 3; 11]

(ЕКК), дата і номер її рішення; вид експертизи, експертна спеціальність; місце роботи, місцезнаходження, номер та строк дії свідоцтва або документа, що підтверджує наявність кваліфрікації судового експерта (якщо видачу свідоцтва не передбачено, вноситься відповідний запис); вид експертизи, експертна спеціальність; місце роботи, місцезнаходження, адреса електронної пошти (для судових експертів, які не $є$ працівниками державних спеціалізованих установ) та телефон судового експерта [7].

Ретельний аналіз чинного законодавства, що регулює питання атестації, навчання (стажування) судових експертів, присвоєння їм кваліфрікації та практика діяльності судових експертів свідчить, про те що існують певні прогалини, неврегульованість данихпитань. Це призводить до довгого часу очікування наслідків експертизи ії ініціаторами, значної завантаженості експертів та притягнення до процесу експертизи осіб 3 невисокою кваліфрікацією. До основних мотивів ситуації, що склалася, необхідно віднести: недостатня врегульованість процедури проходження атестації; незлагодженість вимог щодо судових експертів-економістів; неналежною рівень оплати праці експертів; значна вартість стажування тощо [7].
Отже враховуючи представлений матеріал, Савченко І. О. та Глущенко С. І. зазначають, що на фроні характерного для України явища «законодавчої інсрляції» судові експерти слушно зауважують, що часті зміни правового регулювання унеможливлюють використання зареєстрованих методик, адже іншим стає й алгоритм проведення експертних досліджень, змінюється перелік об'єктів дослідження [12, с. 292]. Отже, стабільність нормативно-правового регулювання $€$ невід'ємною часткою забезпечення плодотворної роботи суб'єктів судово-експертної діяльності.

Крім згаданих раніше нормативно-правових актів, окремі питання судових експертиз регулюються ще й такими документами: Кримінальним процесуальним, Цивільним процесуальним, Господарським процесуальним кодексами України, Кодексом України про адміністративні правопорушення, Кодексом адміністративного судочинства України, Митним кодексом України, Про виконавче провадження а також міжнародними, національними та галузевими стандартами, технічними умовами, правилами, нормами, положеннями, інструкціями, наказами, рекомендаціями, переліками, настановчими документами Держспоживстандарту України [3]. Зокрема, 
якщо розглядати економічну експертизу, то це можуть бути: Податковий кодекс України, Закон України «Про бухгалтерський облік та фрінансову звітність в Україні», П(С)БО, НП(С)БО, МСБО, МСФЗ та інші документи, що регулюють певні операції в цій сорері.

Отже, практика свідчить про наявність та необхідність удосконалення слабких сторін процесу економічної експертизи в Україні, через те що вона є визначним засобом захисту інтересів фрізичних та юридичних осіб, сприяє ефективному розслідуванню, виконує ряд важливіших завдань для виявлення порушень трудового законодавства, визначення розміру втрат від правопорушень в організації праці, а також убезпечує розроблення пропозицій щодо профрілактики негативних явищ. Нині в процесі здійснення економічної експертизи виникає ряд проблем, для подолання яких у майбутньому необхідно запровадити зміни до існуючих законодавчих актів, що спрямовані на вдосконалення регулювання та організації економічної експертизи [1, с. 37].
Висновки. Важливою умовою ефективного проведення економічної експертизи та роботи судових експертів-економістів $\epsilon$ нормативно-правове забезпечення. Це $є$ не тільки вагомим складником внутрішньої кримінально-процесуальної політики, а й важливим свідченням для міжнародної спільноти, де Україна хоче гармонізувати шаблони правоохоронної діяльності та законодавство в межах співпраці з європейським товариством.

Оцінка нормативно-правого регулювання організації та проведення економічних експертиз, роботи судових експертів свідчить, що в Україні прийнято ряд нормативно-правих актів в цій сорері. Проте, на сьогодні в сорері законодавства судових експертиз, як свідчать науковці та практики, є чимало прогалин, недоліків та загроз, які потребують вирішення. Представленні в даному дослідженні удосконалення нормативно-правої бази судово-економічних експертиз, впливатимуть на підвищення ефективності проведення судово-економічних експертиз та роботи судових експертів.

\section{СПИСОК ВИКОРИСТАНИХ ДЖЕРЕЛ:}

1. Mulyk Ya. Economic expertise in Ukraine: theoretical and practical aspects. East European Scientific Journal. 2020. № 3(55). P. 27-38.

2. Інструкція про особливості здійснення судово-експертної діяльності атестованими судовими експертами, що не працюють у державних спеціалізованих експертних установах : Наказ Міністерства юстиції України від 12.12.2011 № 3505/5. URL: https://zakon.rada.gov.ua/laws/show/z1431-11\#Text

3. Інструкція про призначення та проведення судових експертиз та експертних досліджень : Наказ Міністерства юстиції України від 08.10.1998 № 53/5. URL: https://zakon.rada.gov.ua/laws/show/z0705-98

4. Кощинець М.І. Проблеми нормативно-правового та інформаційного забезпечення судово-бухгалтерських експертиз і шляхи їх вирішення. Інноваційна економіка. 2019. № 3-4. С. 168-174.

5. Крівцова Т.О. Вдосконалення правового забезпечення судово-економічної експертизи як форми економічного контролю. Бізнес-Інформ. 2015. № 3. С. 48-53.

6. Мулик Т.О., Мулик Я.І. Теоретичні основи судово-економічної експертизи: аналіз наукових поглядів. Економічний простір. 2021. № 165. C. 131-139. DOI: https://doi.org/10.32782/2224-6282/165-24

7. Мулик Я.І. Організація підготовки та атестації судових експертів: основні вимоги та обмеження. Ефективна економіка. 2021. № 1. URL: http://www.economy.nayka.com.ua/?op=1\&z=8545. DOI: 10.32702/ 2307-2105-2021.1.105

8. Науково-методичні рекомендації з питань підготовки та призначення судових експертиз та експертних досліджень : Наказ Міністерства юстиції України 08.10.1998 № 53/5. URL: https://zakon.rada.gov.ua/laws/show/z0705-98

9. Пиріг І.В. Класифрікація судових експертиз і проблеми вдосконалення законодавства. Актуальні питання судової експертизи та криміналістики : зб. матеріалів міжнар. наук.-практ. конф., присвяч. 95-річчю створення Харків. НДІ суд. експертиз ім. Засл. профр. М.С. Бокаріуса (Харків, 10-11 жовт. 2018 р.). Харків : Право, 2018. С. 25-27.

10. Порядок ведення державного Реєстру атестованих судових експертів : Наказ Міністерства юстиції України від 29.03.2012 № 492/5. URL: https://zakon.rada.gov.ua/laws/show/z0484-12\#Text

11. Про судову експертизу : Закон України від 25.02.1994 № 4038-XII. URL: https://zakon.rada.gov.ua/laws/ show/4038-12

12. Савченко І.О., Глущенко С.І. Проблемні питання при застосуванні в експертній практиці методик проведення судово-економічних експертиз. Криминалистика и судебная экспертиза. 2013. Вип. 58(2). С. 498-502.

13. Хомутенко В.П., Костіна О.Ю. Теорія та практика проведення судових експертиз за напрямками інженерних, економічних, товарознавчих видів досліджень та оціночної діяльності : монографрія. Одеса : ОНЕУ, 2018. 274 c. 


\section{REFERENCES:}

1. Mulyk, Ya. (2020). Economic expertise in Ukraine: theoretical and practical aspects. East European Scientific Journal, 3(55), 27-38.

2. Ministerstvo Yustytsii Ukrainy (2011). Instruktsiia pro osoblyvosti zdiisnennia sudovo-ekspertnoi diialnosti atestovanymy sudovymy ekspertamy, shcho ne pratsiuiut u derzhavnykh spetsializovanykh ekspertnykh ustanovakh [Instructions on the appointment and conduct of forensic examinations and expert studies]. Available at: https://zakon.rada.gov.ua/laws/show/z1431-11\#Text (in Ukrainian)

3. Ministerstvo Yustytsii Ukrainy (1998). Instruktsiia pro pryznachennia ta provedennia sudovykh ekspertyz ta ekspertnykh doslidzhen [Instructions on the appointment and conduct of forensic examinations and expert studies]. Available at: https://zakon.rada.gov.ua/laws/show/z0705-98 (in Ukrainian)

4. Koshchynets, M.I. (2019). Problemy normatyvno-pravovoho ta informatsiinoho zabezpechennia sudovo-bukhhalterskykh ekspertyz i shliakhy yikh vyrishennia [Problems of normative-legal and information support of forensic accounting examinations and ways of their solution]. Innovatsiina ekonomika - Innovative economy, 3-4, 168-174. (in Ukrainian)

5. Krivtsova, T.O. (2015). Vdoskonalennia pravovoho zabezpechennia sudovo-ekonomichnoi ekspertyzy yak formy ekonomichnoho kontroliu [Improving the legal support of forensic economic expertise as a form of economic control]. Biznes-Inform - Business-Inform, 3, 48-53. (in Ukrainian)

6. Mulyk, T.O., \& Mulyk, Ya.I. (2021) Teoretychni osnovy sudovo-ekonomichnoi ekspertyzy: analiz naukovykh pohliadiv [Theoretical foundations of forensic economic examination: analysis of scientific views]. Ekonomichnyi prostir - Economic space, 165, 131-139. DOI: https://doi.org/10.32782/2224-6282/165-24 (in Ukrainian)

7. Mulyk, Ya.I. (2021). Orhanizatsiia pidhotovky ta atestatsii sudovykh ekspertiv: osnovni vymohy ta obmezhennia [Organization of training and certification of forensic experts: basic requirements and limitations]. Efektyvna ekonomika - Efficient economy, 1. URL: http://www.economy.nayka.com.ua/?op= 1\&z=8545. DOI: 10.32702/2307-21052021.1.105 (in Ukrainian)

8. Ministerstvo Yustytsii Ukrainy (1998). Naukovo-metodychni rekomendatsii z pytan pidhotovky ta pryznachennia sudovykh ekspertyz ta ekspertnykh doslidzhen [Scientific and methodological recommendations on the preparation and appointment of forensic examinations and expert studies]. Available at: https://zakon.rada.gov.ua/laws/ show/z0705-98 (in Ukrainian)

9. Pyrih, I.V. (2018). Klasyfikatsiia sudovykh ekspertyz i problemy vdoskonalennia zakonodavstva. Aktualni pytannia sudovoi ekspertyzy ta kryminalistyky [Classification of forensic examinations and problems of improving legislation]. Materialiv mizhnar. nauk.-prakt. konf., prysviach. 95-richchiu stvorennia Kharkiv. NDI sud. ekspertyz im. Zasl. prof. M. S. Bokariusa - Current issues of forensic science and criminology: Coll. materials international. scientific-practical conf., dedicated. 95th anniversary of Kharkiv. Research Institute Court. examinations. Zasl. prof. M.S. Bokarius (Kharkiv, October 10-11, 2018), 25-27. (in Ukrainian)

10. Ministerstvo Yustytsii Ukrainy (2012). Poriadok vedennia derzhavnoho Reiestru atestovanykh sudovykh ekspertiv [The procedure for maintaining the state Register of certified forensic experts]. Available at: https://zakon.rada.gov.ua/laws/show/z0484-12\#Text (in Ukrainian)

11. The Verkhovna Rada of Ukraine (1994) The Law of Ukraine «About forensic examination» № 4038-XII. Available at: https://zakon.rada.gov.ua/laws/show/4038-12 (in Ukrainian)

12. Savchenko, I.O., \& Hlushchenko, S.I. (2013). Problemni pytannia pry zastosuvanni v ekspertnii praktytsi metodyk provedennia sudovo-ekonomichnykh ekspertyz [Problematic issues in the application of methods of forensic economic examinations in expert practice]. Krymynalystyka y sudebnaia ekspertyza - Forensics and forensics, 58(2), 498-502. (in Ukrainian)

13. Khomutenko, V.P., \& Kostina O.Yu. (2018). Teoriia ta praktyka provedennia sudovykh ekspertyz za napriamkamy inzhenernykh, ekonomichnykh, tovaroznavchykh vydiv doslidzhen ta otsinochnoi diialnosti [Theory and practice of forensic examinations in the areas of engineering, economic, commodity research and evaluation]. Odessa: ONEU. (in Ukrainian) 